\title{
Communication \\ Tectonics-Related Geosites: Towards Accurate Nomenclature
}

\author{
Dmitry A. Ruban ${ }^{1,2, *}$, Anna V. Mikhailenko ${ }^{3}$ a and Vladimir A. Ermolaev 4 \\ 1 K.G. Razumovsky Moscow State University of Technologies and Management (the First Cossack University), \\ Zemlyanoy Val 73, Moscow 109004, Russia \\ 2 Department of Economics and Management, Business School, Cherepovets State University, \\ Sovetskiy Avenue 10, Cherepovets, Vologda Region 162600, Russia \\ 3 Department of Physical Geography, Ecology, and Nature Protection, Institute of Earth Sciences, \\ Southern Federal University, Zorge Street 40, Rostov-on-Don 344090, Russia; avmihaylenko@sfedu.ru \\ 4 T.F. Gorbachev Kuzbass State Technical University (KuzSTU), Vesennyaya Street 28, Kemerovo 650000, \\ Russia; ermolaevvla@rambler.ru \\ * Correspondence: ruban-d@rambler.ru
}

Received: 9 June 2019; Accepted: 20 June 2019; Published: 22 June 2019

check for updates

\begin{abstract}
Accurate nomenclature of geological heritage sites (geosites) is necessary to facilitate their description and territorial geodiversity evaluation (both important for sustainable development and efficient land-use planning). As suggested by previous geological heritage studies, tectonics-related geosites are termed differently and, chiefly, provisionally (e.g., as tectonic geosites or structural geosites). Moreover, the nomenclature should take into account modern advances in the understanding of some basic tectonic phenomena. We propose abandoning the separation of structural, neotectonic, and seismic types of geosites and replacing with a single tectonic type. This can be further subdivided into subtypes, although one should consider the complexities in the links between tectonic and other geological phenomena (e.g., unique seismic features are essentially tectonic, but these can be expressed via geomorphological or sedimentary features-a geosite retains tectonic and geomorphological/sedimentary types in this case). The development of accurate nomenclature of tectonics-related geosites requires debates by experts in geological heritage.
\end{abstract}

Keywords: earthquakes; geological heritage; neotectonics; structures; terminology

\section{Introduction}

Geological heritage studies guide the rapidly changing direction of geoscience research [1-3]. Very different unique geological and geomorphological phenomena are reported from more and more places around the world, and this information feeds development of complex ideas such as geodiversity [4], geosystem services [5], and geoaesthetics [6-8]. These ideas are relevant to the general issues of sustainable development and land-use planning. Description and evaluation of geological heritage sites (geosites) require their precise nomenclature(s). Some versions of the latter have been proposed by Bradbury [9], Habibi et al. [10], Prosser et al. [11], and Ruban [12]. Many particular solutions have been offered in the case studies aimed at regional geological heritage characterization and geodiversity evaluation. Two principal approaches for developing geosite nomenclature dominate the research. One approach is based on classification of unique phenomena (sedimentary, structural, geomorphological, etc.). Another approach focuses on the form pf representation of such phenomena (natural outcrop, roadcut, quarry, etc.). In fact, both approaches are utile and contribute to geological heritage description and evaluation [10].

The phenomena-based approach faces significant difficulties because it requires consideration of various geological objects and processes, which can be classified very differently. Geosite types 
and subtypes can be established only provisionally, and construction of a really balanced, accurate nomenclature remains a desirable but almost unachievable task. Moreover, the nomenclature depends on the current understanding of the relevant phenomena. Any transformation in geoscience concepts and paradigms makes geosite nomenclature correction urgent. A typical example is tectonics-related geosites. On the one hand, different researchers tend to define them differently. Habibi et al. [10] reserved as much as three types for these geosites (structural, neotectonic, and seismic). On the other hand, there have been significant advances in the classification of tectonic phenomena [13], which should be fully taken into consideration. The objective of this brief paper is to consider the evidence of tectonics-related geosites and to make tentative proposals for making their nomenclature more accurate. This chiefly terminological paper does not pretend to explore the comprehensive characteristics of these sorts of geosites. This remains a task for future research.

\section{Experience-Based Evidence}

Unique tectonic features have been reported from many geosites. The serious question is how these features were termed. Several examples demonstrating the diversity of options are given below.

Tectonic features (general term): Basilone and Di Maggio [14] suggested that the Monte Gallo geosite (Italy) boasted tectonic peculiarities. Panizza [7] noted that some key unique geological features representing in the geosites of the Dolomites (Italy) are tectonic. The tectonic elements of the geological heritage of the Viana Do Castelo Municipality (Portugal) were considered by Carvalhido et al. [15].

Structural features (structures such as fold, faults, nappes, etc.): Erikstad et al. [16] mentioned structural features as components of the geological heritage of the Oslo area (Norway). Structural uniqueness was reported for the Minas do Camaquã Geosite Protection Area (Brazil) by Von Ahn and Simon [17]. Nazaruddin [18] recognized structural sites in the Deli District (Malaysia). The Khamyshki-Lipovaja geosite (Western Caucasus, Russia) provided the opportunity to observe structures, namely simple folds and faults [19], and in more recent investigations excellent natural exposures of these structural elements were found (Figure 1).

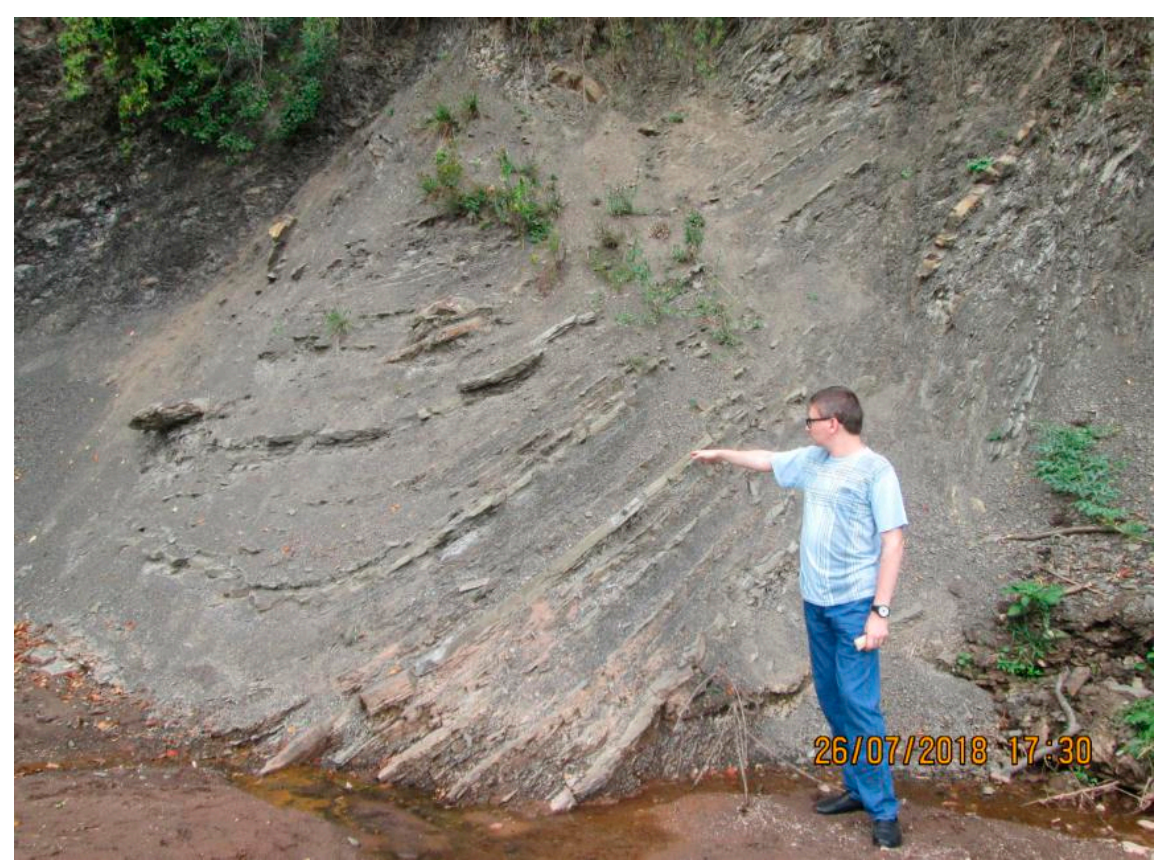

Figure 1. Small fold (left) and thrust (right) in the Khamyshki-Lipovaja geosite (photo by N.V. Ruban).

Neotectonic features (Late Cenozoic tectonic activity): Kazanci [20] suggested that the relevance of some geosites near Ankara to the neotectonic development of the western Pontides stresses their uniqueness. The Azish-Tau 4500 viewpoint geosite in Mountainous Adygeya (Russia) offers 
a panoramic view of the landforms (mountain ranges and the river valley), providing a clue to the understanding of the neotectonic uplift of the Western Caucasus (Figure 2).

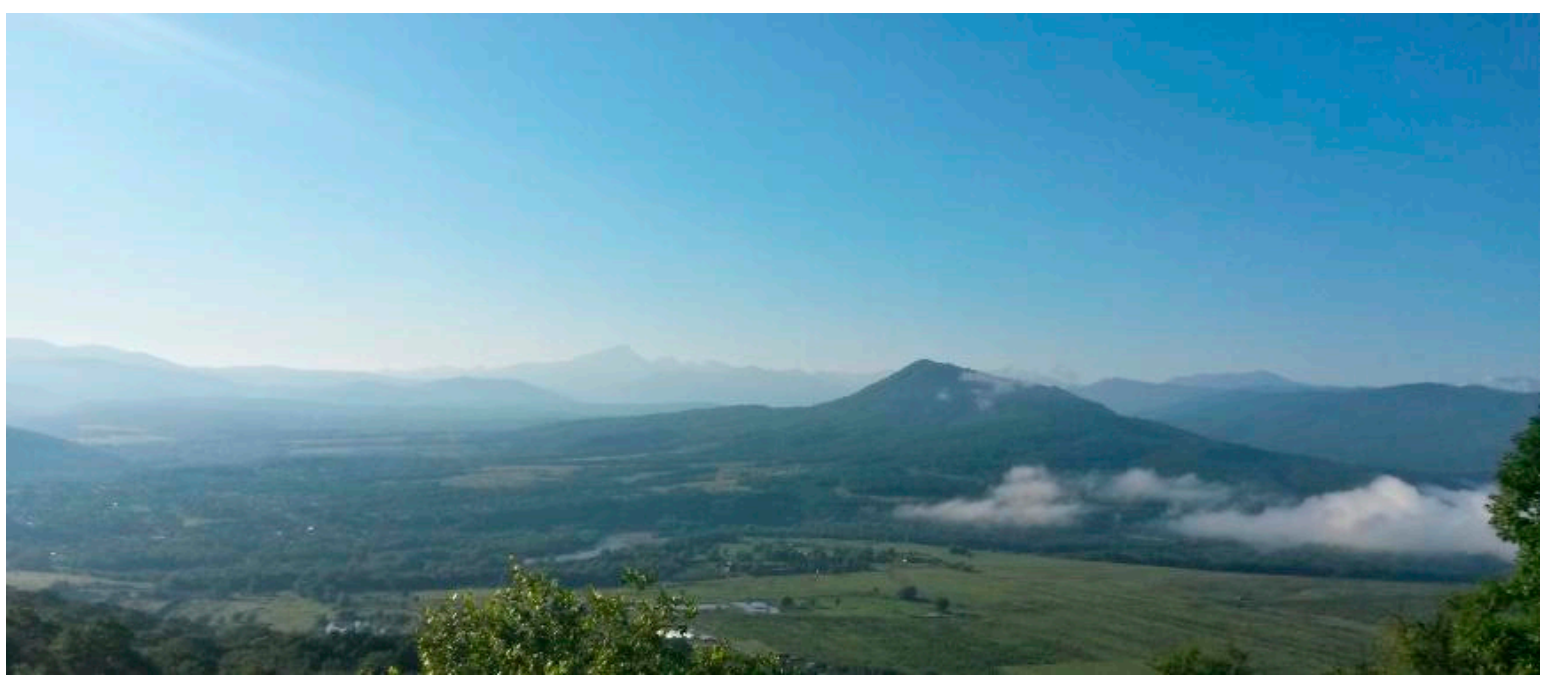

Figure 2. The Azish-Tau 4500 viewpoint geosite displaying landforms created by partly differential neotectonic uplift of the Western Caucasus (photo by A.V. Mikhailenko).

(Palaeo)seismic features (signatures of recent and past earthquakes): Piacentini et al. [21] characterized the Mount Serrone fault geosite (Italy) as representing seismic activity. Tang [22] reported on the Hanwang Earthquake Memorial Park (China), which displays the consequences of a big recent earthquake. Üner et al. [23] suggested seismites exposed near the Lake Van (Turkey) as a kind of geological heritage. The morphology of the Monakh Mountain geosite (Figure 3) and individual blocks at its toe are evidence of the regular seismic activity in the Western Caucasus (Russia).

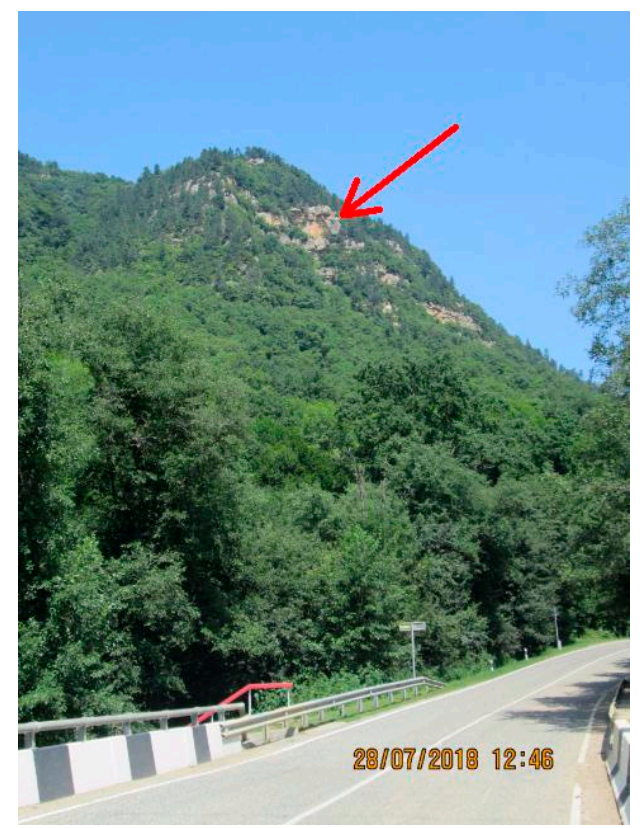

Figure 3. The Monakh Mountain geosite showing cliffs (red arrow) sculptured partly by huge block detachment after small historical and recent earthquakes (photo by D.A. Ruban).

\section{Discussion and Conclusions}

The experience-based evidence given above implies that tectonics-related geosites are termed in different ways, and the preferred nomenclature remains vague. For instance, the same features 
(e.g., exposed folds) can be called either tectonic or structural. Some typical structural elements (e.g., faults) can be related to both neotectonic activity and seismicity [21]. Moreover, many unique tectonics-related features are essentially geomorphological.

Tectonics is a vast field of knowledge, although it has become common to make distinction between tectonics sensu stricto, neotectonics, active tectonics, and seismicity. The main reason is that relevant features represent different times and rates of tectonic processes. However, the "fresh" synthesis of the tectonic knowledge provided by $\mathrm{Wu}$ and $\mathrm{Hu}$ [13] implies that the terms used for these phenomena are haphazard (neotectonics and active tectonics have been defined in different geologic time frames), closely related (seismicity is linked to both neotectonics and active tectonics), and understood in connection to some other fields of geoscience research (e.g., neotectonics 'enters' the field of geomorphology). The 'boundaries' between the relevant definitions seems to be smooth. In such cases, it is sensible neither to continue mixing the basic terms (as suggested by the experience-based evidence), nor to separate several types of tectonics-related geosites (as proposed by Habibi et al. [10] and Ruban [13]). A single type, namely the tectonic type, seems to be preferable. This type has to embrace geological heritage representing the both tectonic objects (folds, faults, etc.) and tectonic processes (modern and ancient). Indeed, some processes are too large-scale (e.g., lithospheric plate motion), too deep (e.g., mantle plume emplacement), and/or too slow (e.g., orogenesis). However, if the relevant features are unique, the geosites representing these features have limited visibility, which is not so uncommon in the practice of geological heritage management [24].

Depending on the needs of particular research projects, the tectonic type geosites can be subdivided into several subtypes by the same principle with which paleogeographical geosites were classified [25]. However, two complexities should be noted (Figure 4). First, tectonic objects and processes are usually visualized via structures. If this is the case, it is possible to restrict the definition of the structural subtype to only the natural 'geometrical' forms. Second, some subtypes seeming to be obvious (from the point of view of tectonics) are located, in fact, at an intersection of different fields of geoscience knowledge. The three typical situations are as follows (Figure 4).

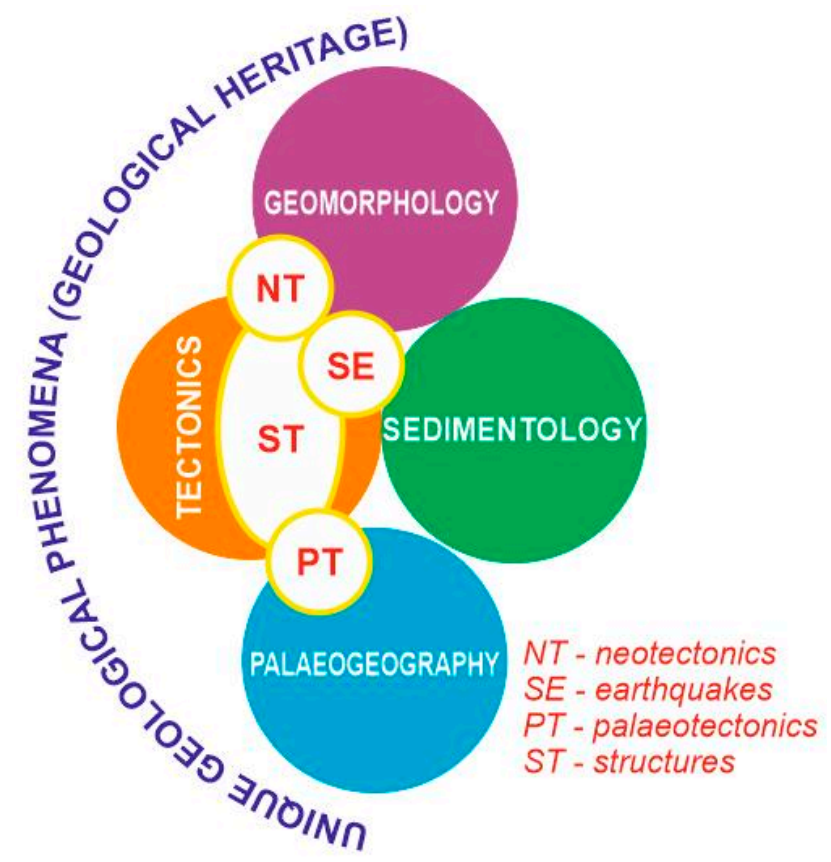

Figure 4. Conceptual representation of some principal tectonics-related constituents of geological heritage.

Tectonics-anchored intersection: Geosites demonstrating seismic activity are essentially tectonic, though this activity can be expressed by geomorphological (surface ruptures) or sedimentary (seismite 
deposits) features. This subtype should be included in the tectonic type, although geosites bearing this subtype are complex, i.e., they include tectonic and geomorphological/sedimentary types.

Other discipline-anchored intersection: Geosites demonstrating an affinity to past continental blocks (e.g., affinity to Rodinia) or terrane chains (e.g., affinity to the Galatian Superterrane) provide important information for palaeotectonic reconstructions. However, these are more relevant to the configuration of land and water masses, i.e., to palaeogeography, and these geosites should be attributed to a particular subtype of the palaeogeographical type.

Compromise intersection: Neotectonic geosites are linked to both tectonic activity and landform evolution. Although these represent tectonic development according to the modern stress field, these geosites look 'physically' like landforms. In such cases, it is unnecessary to separate the neotectonical type or to distinguish the neotectonical subtype within either the tectonic or geomorphological types. It appears better to judge such geosites as complex and as belonging simultaneously to the tectonic and geomorphological types; in each case, a proper subtype can be chosen.

In conclusion, this paper highlights the nomenclatural complexity of tectonics-related geosites. The currently observed inconsistencies in terminology and definitions should be avoided. Only the tectonic type of geosite should be distinguished. Further discussions and negotiations between world experts in geological heritage are necessary to fix the problem and to make the nomenclature of tectonics-related geosites more accurate. This is particularly necessary to facilitate the assessment of territorial geological resources. For instance, the accurate nomenclature of geosites improves geodiversity evaluation, the outcomes of which are important for efficient land management.

Tectonics-related geosites provide an example of unjustified nomenclature in geosite typology. The development of this nomenclature should be conducted by experts from particular fields of geosciences, as well as by specialists in geological heritage. Moreover, it is sensible to apply the modern approaches of content analysis to the professional texts and web-pages in order to make judgments about the frequency of use of different terms and to detect terminological preferences within the international research community.

Author Contributions: Conceptualization, D.A.R.; field work, A.V.M. and D.A.R.; methodology, D.A.R. and V.A.E.; investigation, A.V.M. and D.A.R.; writing, D.A.R. and V.A.E.

Funding: This research received no external funding.

Acknowledgments: The authors gratefully thank the journal editor and the three reviewers for their thorough consideration of this paper, as well as N.V. Ruban (Russia) for field assistance.

Conflicts of Interest: The authors declare no conflict of interest.

\section{References}

1. Henriques, M.H.; dos Reis, R.P.; Brilha, J.; Mota, T. Geoconservation as an Emerging Geoscience. Geoheritage 2011, 3, 117-128. [CrossRef]

2. Prosser, C.D. Our rich and varied geoconservation portfolio: The foundation for the future. Proc. Geol. Assoc. 2013, 124, 568-580. [CrossRef]

3. Reynard, E.; Brilha, J. Geoheritage: Assessment, Protection, and Management; Elsevier: Amsterdam, The Netherland, 2018; pp. 1-482.

4. Gray, M. Geodiversity Valuing and Conserving Abiotic Nature; Wiley-Blackwell: Chichester, UK, 2013; pp. 1-495.

5. Ruban, D.A.; Tiess, G.; Sallam, E.S.; Ponedelnik, A.A.; Yashalova, N.N. Combined mineral and geoheritage resources related to kaolin, phosphate, and cement production in Egypt: Conceptualization, assessment, and policy implications. Sustain. Environ. Res. 2018, 28, 454-461. [CrossRef]

6. Mikhailenko, A.V.; Nazarenko, O.V.; Ruban, D.A.; Zayats, P.P. Aesthetics-based classification of geological structures in outcrops for geotourism purposes: A tentative proposal. Geologos 2017, 23, 45-52. [CrossRef]

7. Panizza, M. Outstanding Intrinsic and Extrinsic Values of the Geological Heritage of the Dolomites. Geoheritage 2018, 10, 607-612. [CrossRef] 
8. Xu, H.; Cui, Q.; Ballantyne, R.; Packer, J. Effective environmental interpretation at Chinese natural attractions: The need for an aesthetic approach. J. Sustain. Tour. 2013, 21, 117-133. [CrossRef]

9. Bradbury, J. A keyed classification of natural geodiversity for land management and nature conservation purposes. Proc. Geol. Assoc. 2014, 125, 329-349. [CrossRef]

10. Habibi, T.; Ponedelnik, A.A.; Yashalova, N.N.; Ruban, D.A. Urban geoheritage complexity: Evidence of a unique natural resource from Shiraz city in Iran. Resour. Policy 2018, 59, 85-94. [CrossRef]

11. Prosser, C.; Murphy, M.; Larwood, J. Geological Conservation: A Guide to Good Practice; English Nature: Peterborough, UK, 2006; pp. 1-145.

12. Ruban, D.A. Quantification of geodiversity and its loss. Proc. Geol. Assoc. 2010, 121, 326-333. [CrossRef]

13. Wu, Z.; Hu, M. Neotectonics, active tectonics and earthquake geology: Terminology, applications and advances. J. Geodyn. 2019, 127, 1-15. [CrossRef]

14. Basilone, L.; Di Maggio, C. Geology of Monte Gallo (Palermo Mts, NW Sicily). J. Maps 2016, 12, $1072-1083$. [CrossRef]

15. Carvalhido, R.J.; Brilha, J.B.; Pereira, D.I. Designation of Natural Monuments by the Local Administration: The Example of Viana Do Castelo Municipality and its Engagement with Geoconservation. Geoheritage 2016, 8, 279-290. [CrossRef]

16. Erikstad, L.; Nakrem, H.A.; Markussen, J.A. Protected Geosites in an Urban Area of Norway, Inventories, Values, and Management. Geoheritage 2018, 10, 219-229. [CrossRef]

17. Von Ahn, M.M.; Simon, A.L.H. Geomorphological mapping and geodiversity: Study at the Minas do Camaquã Geosite Protection Area. Rev. Bras. De Geomorfol. 2017, 18, 427-442. [CrossRef]

18. Nazaruddin, D.A. Systematic Studies of Geoheritage in Jeli District, Kelantan, Malaysia. Geoheritage 2017, 9 , 19-33. [CrossRef]

19. Ruban, D.A.; Zorina, S.O.; Morozov, V.P.; Galiullin, B.M.; Eskin, A.A.; Nikashin, K.I. The Khamyshki-Lipovaja section-A new geosite displaying unstable palaeoenvironments of the Early-Middle Jurassic semi-enclosed sea on the northern Neo-Tethyan margin. Nat. Nascosta 2018, 52, 37-54.

20. Kazanci, N. Geological Background and Three Vulnerable Geosites of the KidotlesszidotlesslcahamamÇamlidotlessdere Geopark Project in Ankara, Turkey. Geoheritage 2012, 4, 249-261. [CrossRef]

21. Piacentini, T.; Miccadei, E.; Berardini, G.; Aratari, L.; De Ioris, A.; Calista, M.; Carabella, C.; D’arielli, R.; Mancinelli, V.; Paglia, G.; et al. Geological tourist mapping of the Mount Serrone fault geosite. J. Maps 2019, 15, 298-309. [CrossRef]

22. Tang, Y. Contested Narratives at the Hanwang Earthquake Memorial Park: Where Ghost Industrial Town and Seismic Memorial Meet. Geoheritage 2019, 11, 561-575. [CrossRef]

23. Üner, S.; Aliriz, M.G.; Özsayin, E.; Selçuk, A.S.; Karabiyikoglu, M. Earthquake Induced Sedimentary Structures (Seismites): Geoconservation and Promotion as Geological Heritage. Geoheritage 2017, 9, 133-139. [CrossRef]

24. Mikhailenko, A.V.; Ruban, D.A. Geo-Heritage Specific Visibility as an Important Parameter in Geo-Tourism Resource Evaluation. Geosciences 2019, 9, 146. [CrossRef]

25. Bruno, D.E.; Crowley, B.E.; Gutak, J.M.; Moroni, A.; Nazarenko, O.V.; Oheim, K.B.; Ruban, D.A.; Tiess, G.; Zorina, S.O. Paleogeography as geological heritage: Developing geosite classification. Earth Sci. Rev. 2014, 138, 300-312. [CrossRef]

(C) 2019 by the authors. Licensee MDPI, Basel, Switzerland. This article is an open access article distributed under the terms and conditions of the Creative Commons Attribution (CC BY) license (http://creativecommons.org/licenses/by/4.0/). 